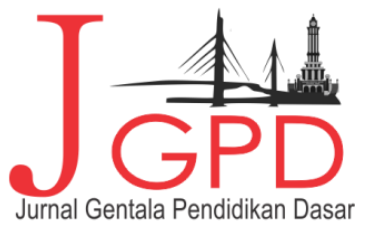

JURNAL GENTALA PENDIDIKAN DASAR Vol.3 No. I June 2018 Page 73-9I
P-ISSN : 2614-7092, E-ISSN : 2621-961l
Available Dnline at: http://online-journal.unja.ac.id/index.php/gentala
email : penyunting.jurnal.g-pgsd国unja.ac.id

Research Article

\title{
Pelaksanaan Pengelolaan Kelas Di Sekolah Dasar
}

Budi Purnomol, Febliana Aulia ${ }^{2}$

${ }^{1)}$ PIPS FKIP Universitas Jambi ${ }^{2)}$ PGSD FKIP Universitas Jambi, Jambi, Indonesia

\begin{tabular}{l} 
Article Information \\
Reviewed : Feb 20, 2018 \\
Revised : April 10, 2018 \\
Available Online : Jun 29, 2018 \\
\\
\hline $\begin{array}{l}\text { Keyword } \\
\text { class management, elementary } \\
\text { school }\end{array}$
\end{tabular}

Corespondence

e-mail :

budi.purnomo@unja.ac.id
This study aims to describe the implementation of classroom management in fourth grade students of 77/I Penerokan primary schools, Bajubang District. This research is a qualitative descriptive study. The informant of this study was the fourth grade teacher. Data collection techniques are observation, interviews, and documentation. The results of the study are classroom management carried out by the teacher first arranging students who are in the classroom, namely by making the class organizational structure include the class leader, vice class chairman, secretary, treasurer and sections of fields such as sports, arts, cleanliness, security and social. The teacher provides oversight of the implementation of the duties of each student who has a position in the class organization. After that, the implementation of classroom management continued with the arrangement of class facilities including arranging student seats, namely all students facing the board. Students sit in pairs. The teacher's desk is in front of the student's left. while the blackboard is in the middle. Teaching tools such as hero pictures and traditional house drawings and traditional clothes of all provinces in Indonesia are neatly hung on the walls of the classroom, although there are not too many

\section{PENDAHULUAN}

Pengelolaan kelas yang efektif merupakan persyaratan mutlak bagi terjadinya proses belajar mengajar. Mengajar pada prinsipnya membimbing siswa dalam kegiatan belajar mengajar atau mengandung pengertian bahwa mengajar merupakan suatu usaha pengorganisasian lingkungan dalam hubungannya dengan anak didik dan bahan pengajar yang menimbulkan proses belajar.

Dari penjelasan di atas mengandung makna bahwa guru-lah yang mengatur, mengawasi dan mengelola kelas agar tercapainya proses belajar mengajar yang berarah kepada tujuan-tujuan pendidikan. Di samping itu pula, guru bertanggung jawab memelihara lingkungan fisik kelasnya 


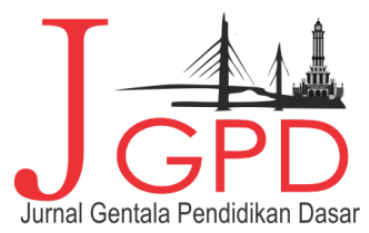

JURNAL GENTALA PENDIDIKAN DASAR Vol.3 No. I June 2018 Page 73-91

P-ISSN : 2614-7092, E-ISSN : 2621-9611

Available Online at: http://online-journal.unja.ac.id/index.php/gentala

email : penyunting.jurnal.g-pgsd国unja.ac.id

agar senantiasa menyenangkan untuk belajar dan lingkungan yang baik adalah yang bersifat menantang dan merangsang.

Adapun pelaksanaan kegiatan pengelolaan kelas pada siswa kelas IV SDN 77/I Penerokan meliputi :

1. Pengeloaan kelas yang menyangkut siswa

2. Pengeloaan fisik (ruangan, perabot, alat belajar)

Kedua hal tersebut perlu dikelola secara baik dalam rangka menghasilkan suasana yang kondusif bagi terciptanya pembelajaran yang baik pula. Pelaksanaan pengelolaan kelas di SDN 77/I Penerokan adalah merupakan usaha untuk menciptakan kondisi belajar yang menyenangkan, agar siswa lebih nyaman dalam mengikuti proses pembelajaran.

Dalam proses belajar-mengajar, kondisi kelas yang nyaman akan membantu tersampaikannya materi yang diajarkan oleh guru terhadap peserta didik. Guru dituntut memiliki keterampilan di dalam mengelola komponen-komponen pembelajaran, yang dapat membuat suasana proses belajar-mengajar berjalan secara efektif.

Guru harus mampu merubah suasana kelas yang dapat membuat siswa menjadi bersemangat dalam mengikuti kegiatan belajar-mengajar. Dengan semangat yang dimiliki, baik dari guru maupun peserta didik, maka interaksi antara guru dan peserta didik dalam proses belajar-mengajar dapat berjalan dengan menyenangkan.

Seorang guru harus dapat melakukan pengelolaan kelas sebaik mungkin demi tercapainya proses pembelajaran yang nyaman bagi peserta didik. Menurut Rusman (2010:271) Kegiatan guru dalam mengelola kelas meliputi kegiatan pengaturan siswa, pengaturan tempat belajar, pemilihan bentuk kegiatan, pemilihan media pembelajaran, penilaian. Sebagai indikator keberhasilan guru dalam menciptakan kondisi yang memungkinkan dengan melakukan pengelolaan kelas dapat dilihat pada proses belajar mengajar berlangsung secara efektif.

Adanya pengelolaan kelas yang baik yang dilakukan oleh seorang guru maka, diharapkan dapat memotivasi siswa dalam belajar dikelas. Sehingga aktivitas belajar dapat berjalan dengan lancar.

Meskipun guru telah melakukan pengelolaan kelas, belum sepenuhnya dan dapat dipastikan kelas akan menjadi kondusif. Kepribadian siswa berbeda-beda antara siswa yang satu 


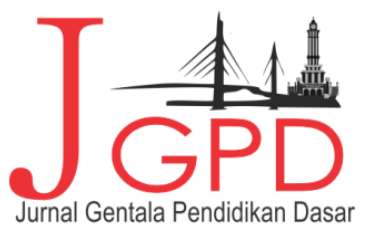

JURNAL geNTALA PENDIDIKAN DASAR Vol.3 №. I June 2018 Page 73-91

P-ISSN : 2614-7092, E-ISSN : 2621-9611

Available Online at: http://online-journal.unja.ac.id/index.php/gentala

email : penyunting.jurnal.g-pgsd回unja.ac.id

dengan yang lain. Kondisi lingkungan siswa juga sangat mempengaruhi konsentrasi siswa dalam belajar di kelas. Selain itu kurangnya dukungan lingkungan dalam memotivasi siswa untuk belajar dapat menyebabkan siswa tidak semangat dalam mengikuti pembelajaran di kelas.

\section{METODE PENELITIAN}

\section{Pendekatan Penelitian}

Penelitian ini menggunakan pendekatan kualitatif yang bersifat deskriptif. Penelitian ini dimaksudkan untuk mendiskripsikan suatu keadaan, melukiskan dan menggambarkan pelaksanaan pengelolaan kelas siswa SDN 77/I Penerokan.

\section{Subjek Penelitian}

Pada penelitian ini, peneliti mengambil subjek penelitian dengan menggunakan teknik purposive sampling yaitu 1 guru kelas IV dan 3 siswa kelas IV dengan alasan peneliti ingin mengetahui pelaksanaan pengelolaan kelas siswa SDN 77/I Penerokan yang dilakukan oleh guru dan siswa kelas IV. Setelah data diperoleh dari guru kelas IV dan siswa kelas IV. Kemudian akan ditriangulasi dengan data yang diperoleh dari guru untuk keakuratan data yang diperlukan dalam penelitian.

\section{Tabel 1. Subjek Penelitian}

\begin{tabular}{lll}
\hline No & Subjek & Keterangan \\
\hline 1. & Endang, S.Pd.I & Guru Kelas IV \\
\hline 2. & Anggi Pratiwi & Siswa Kelas IV \\
\hline 3. & Rahel Ramanda & Siswa Kelas IV \\
\hline 4. & Bimo Saputra & Siswa Kelas IV \\
\hline
\end{tabular}

Sumber : SDN 77/I Penerokan

\section{Lokasi Penelitian}

Penelitian ini dilaksanakan di SDN 77/I Penerokan. Waktu Penelitian ini dilaksanakan pada semester genap tahun 2016/2017. 


\section{Kehadiran Peneliti}

Secara umum kehadiran peneliti dilapangan dilakukan 3 tahap:

1) Penelitian pendahuluan yang bertujuan mengenal lapangan penelitian.

2) Pengumpulan data, dalam bagian ini peneliti secara khusus menyimpulkan data

3) Evaluasi data yang bertujuan menilai data yang diperoleh di lapangan.

\section{Sumber Data dan Data}

Jenis dan sumber data terbagi dua, yaitu pengambilan data yang dihimpun langsung oleh peneliti dan disebut sumber primer, sedangkan apabila melalui tangan kedua disebut data sekunder". Berdasarkan hal tersebut maka peneliti menggunakan sumber data primer dari kegiatan observasi yang dilakukan dan kegiatan wawancara langsung kepada guru kelas dan siswa kelas IV SDN 77/I Penerokan yaitu pelaksanaan pengelolaan kelas siswa SDN 77/I Penerokan. Sedangakan data sekunder yang akan diperoleh peneliti adalah berupa dokumentasi yang ada di sekolah.

Adapun data-data yang diperlukan dalam penelitian ini adalah data yang berkaitan dengan bagaimana pelaksanaan pengelolaan kelas pada siswa kelas IV SDN 77/I Penerokan Kecamatan Bajubang.

\section{Teknik Pengumpulan Data}

\section{Observasi}

Pada penelitian ini, peneliti menggunakan observasi non partisipan, yaitu peneliti tidak terlibat dan hanya sebagai pengamat independen. Peneliti mencatat, menganalisis, dan membuat kesimpulan tentang pelaksanaan pengelolaan kelas pada siswa kelas IV SDN 77/I Penerokan

\section{Tabel 2. Pedoman Observasi}

\begin{tabular}{lcll}
\hline No & Aspek yang diamati & Sub aspek yang diamati & Deskripsi \\
\hline 1. & Pengaturan siswa & 1. & Pembentukan Organisasi \\
& & Siswa \\
& & 2. & Penugasan Siswa \\
& 3. & Pembimbingan Siswa \\
\hline 2. & Pengaturan fasilitas & 1) & Pengaturan Tempat Duduk \\
& & 2) & Pengaturan Alat-alat \\
& & Pengajaran \\
& 3) & Penataan keindahan dan \\
& & kebersihan ruangan kelas \\
& 4) Ventilasi dan Pengaturan \\
\hline
\end{tabular}

Copyright (c) 2018 Budi Purnomo, Febliana Aulia Attribution-NonCommercial-ShareAlike 4.0 International License 76| P a g e 
JURNAL gENTALA PENDIDIKAN DASAR Vol.3 o. I June 2018 Page 73-91

P-ISSN : 2614-7092, E-ISSN : 2621-9611

Available Online at: http://online-juurnal.unja.ac.id/index.php/gentala

email : penyunting.jurnal.g-pgsd回unja.ac.id

\begin{tabular}{|c|c|c|c|}
\hline No & Aspek vang diamati & Sub aspek vang diamati & Deskrinsi \\
\hline
\end{tabular}

Sumber : Ahmad Rohani, (2004:128)

2. Wawancara

Pada penelitian ini peneliti menggunakan wawancara dengan memilih informannya adalah guru kelas sebagai orang yang mengelola kelas.

\section{Tabel 3. Pedoman Wawancara}

\begin{tabular}{|c|c|}
\hline Informan & Pertanyaan \\
\hline \multirow[t]{16}{*}{ Guru kelas IV } & 1. Apa yang Bapak/ibu ketahui tentang pengelolaan kelas? \\
\hline & 2. Dalam pengelolaan kelas, apa saja yang Bapak/ibu lakukan \\
\hline & dalam mengatur atau membentuk kelas yang baik? \\
\hline & 3. Apa saja yang Bapak/ibu gunakan dalam mengelola kelas? \\
\hline & 4. Bagaimana cara membuat kelas yang kondusif? \\
\hline & 5. Bagaimana cara Bapak/ibu dalam membentuk organisasi \\
\hline & siswa? \\
\hline & 6. Bagaimana cara Bapak/ibu memberikan penugasan kepada \\
\hline & siswa? \\
\hline & 7. Bagaimana cara Bapak/ibu dalam membimbing siswa? \\
\hline & 8. Bagaimana pengaturan tempat duduk didalam kelas? \\
\hline & 9. Bagaimana masalah pengaturan alat-alat pengajaran di \\
\hline & dalam kelas? \\
\hline & 10. Bagaimana cara Bapak/ibu dalam menata keindahan ruang \\
\hline & kelas? \\
\hline & 11. Bagaimana pengaturan cahaya di dalam kelas? \\
\hline \multirow[t]{4}{*}{ Siswa kelas IV } & 1. Bagaimana cara siswa dalam mengatur alat-alat pelajaran? \\
\hline & 2. Bagaimana cara siswa menata keindahan ruang kelas? \\
\hline & 3. Bagaimana siswa dalam mengatur tempat duduk? \\
\hline & 4. Bagaimana kondisi dalam pengaturan cahaya? \\
\hline
\end{tabular}




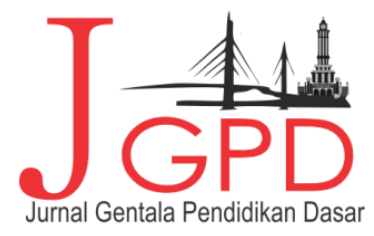

JURNAL GENTALA PENDIDIKAN DASAR Vol.3 No. I June 2018 Page 73-9I
P-ISSN : 2614-7092, E-ISSN : 262I-96II
Available Online at: http://online-jaurnal.unja.ac.id/index.php/gentala
email : penyunting.jurnal.g-pgsd国unja.ac.id

3. Dokumentasi

Menurut Sugiyono (2012:82) dokumentasi merupakan catatan peristiwa yang sudah berlalu. Menurut Syatori dan Komariah (2011:149) menjelaskan studi dokumentasi yaitu mengumpulkan dokumen-dokumen dan data-data yang diperlukan dalam penelitian lalu ditelaan secara intens sehingga dapat mendukung dan menambah keercayaan dan pembuktian suatu kejadian.

\section{Teknik Analisis Data}

Penelitian ini mengacu pada konsep Miles dan Huberman (dalam Sugiyono, 2012:91) yang mengemukakan bahwa aktivitas dalam analisis kualitatif dilakukan secara interaktif dan berlangsung secara terus menerus sampai tuntas sehingga datanya sudah jenuh. Aktivitas dalam analisis data yaitu data reduction, data display, dan conclusion drawing/verification.

\section{Pengecekan Keabsahan Temuan}

Untuk memperoleh keabsahan temuan perlu diteliti kredibilitasnya dengan menggunkan teknik sebagai berikut.

1) Persistent observation (ketekunan pengamatan), yaitu mengadakan observasi secara terus menerus terhadap objek penelitian guna memahami gejala lebih mendalam terhadap berbagai aktifitas yang sedang berlangsung di lokasi penelitian.

2) Triangulasi, yaitu tehnik pemeriksaan keabsahan data yang memanfaatkan sesuatu yang lain dari luar data untuk keperluan pengecekan atau pembanding terhadap data. Triangulasi yang digunakan dalam penelitian ini adalah triangulasi sumber data dengan cara membandingkan dan mengecek balik derajat kepercayaan suatu informasi yang diperoleh melalui waktu dan alat yang berbeda dalam metode kualitatif.

3) Peerderieting (pemeriksaan sejawat melalui diskusi), bahwa yang dimaksud dengan pemeriksaan sejawat melalui diskusi yaitu teknik yang dilakukan dengan cara mengekspos hasil sementara atau hasil akhir yang diperoleh dalam bentuk diskusi analitik dengan rekanrekan sejawat.

\section{Tahap-tahap Penelitian}

Copyright (c) 2018 Budi Purnomo, Febliana Aulia Attribution-NonCommercial-ShareAlike 4.0 International License 


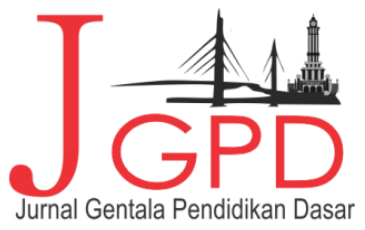

JURNAL geNTALA PENDIDIKAN DASAR Vol.3 No. I June 2018 Page 73-91

P-ISSN : 2614-7092, E-ISSN : 2621-9611

Available Online at: http://online-journal.unja.ac.id/index.php/gentala

email : penyunting.jurnal.g-pgsd国unja.ac.id

Adapun tahap-tahap yang dilakukan oleh peneliti dalam pelaksanaan penelitian adalah sebagai berikut.

1. Tahap Persiapan

1) Menyusun Instrumen Penelitian

Penyusunan instrument penelitian ini disusun berdasarkan tujuan penelitian dan jenis data yang di jadikan sumber penelitian, instrument yang digunakan dalam mengumpulkan data adalah observasi, interview dan dokumentasi.

2) Mendatangi Informan

Agar dalam pelaksanaan penelitian tidak terjadi kesalahpahaman bagi responden, maka penelitian perlu mendatangi responden untuk memberi informasi seperlunya kepada responden.

2. Tahap Pelaksanaan Penelitian

Kegiatan yang dilakukan pada tahap ini adalah mengumpulkan data dengan instrumeninstrumen yang sudah di persiapkan, mengelola data, menganalisis data, dan menyimpulkan data. Dalam kegiatan ini peneliti membawa surat izin dari Fakultas Keguruan dan Ilmu Pendidikan Universitas Jambi untuk mengambil data di lapangan.

3. Tahap Penyelesaian

Kegiatan yang dilakukan dalam tahap ini adalah menyusun data-data yang telah di peroleh dan analisis dalam bentuk laporan hasil penelitian yang di tempatkan pada BAB IV dan BAB V.

\section{HASIL DAN PEMBAHASAN}

\section{Hasil}

Penelitian ini dilaksanakan di SDN 77/1 Penerokan dengan melakukan pengamatan secara langsung mengenai pelaksanaan pengelolaan kelas pada siswa kelas IV SDN 77/I Penerokan Kecamatan Bajubang. Selain melakukan observasi langsung, penulis juga melakukan wawancara terhadap guru kelas IV dan siswa kelas IV. Adapun tujuan dilakukannya wawancara adalah untuk mendapatkan infomasi pelaksanaan pengelolaan kelas di SDN 77/1 Penerokan sebagai pendukung dari hasil observasi yang penulis lakukan. Kemudian penulis juga menggunakan 


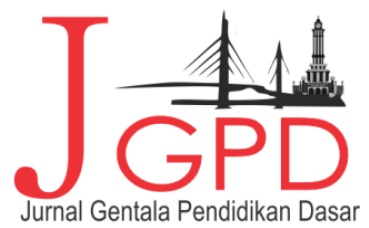

JURNAL gENTALA PENDIDIKAN DASAR Vol.3 No. I June 2018 Page 73-91

P-ISSN : 2614-7092, E-ISSN : 2621-9611

Available Online at: http://online-journal.unja.ac.id/index.php/gentala

email : penyunting.jurnal.g-pgsd国unja.ac.id

teknik dokumentasi untuk mendapatkan bukti fisik pelaksanaan penelitian. Untuk mendeskripsikan hasil penelitian, digunakan matriks hasil penelitian. Berikut uraiannya:

\section{Pengaturan Siswa di Kelas}

Menurut matriks hasil penelitian tersebut, dapat diketahui bahwa SDN 77/1 Penerokan melakukan pengeolaan dengan mengatur keadaan siswa di dalam kelas.

1) Pembentukan Organisasi Siswa

Berdasarkan hasil observasi yang penulis lakukan pada tanggal 14 Maret 2016 dapat diketahui bahwa dalam mengatur siswa, guru terlebih dahulu membuat struktur organisasi kelas meliputi ketua kelas, wakil ketua kelas, sekretaris, bendahara serta seksi-seksi bidang seperti bidang olahraga, seni, kebersihan, keamanan dan sosial. Pembuatan struktur organisasi kelas bertujuan agar guru dapat lebih mudah untuk mengontrol dan mengkondisikan kelas menjadi kelas yang baik dan nyaman sebagai tempat penyelenggaraan pedidikan.

Hasil observasi yang penulis lakukan, didukung dengan hasil wawancara penulis terhadap guru SDN 77/1 Penerokan mengenai cara dalam membentuk organisasi yaitu sebagai berikut:

GR: "Dalam memimilih siswa untuk menjadi anggota organisasi kelas, saya memiliki beberapa kriteria yaitu pertama adalah tingkah laku atau sikap siswa ketika berada di kelas yaitu kriteria baik dan terdapat sikap pemimpin. Kedua adalah nilai pada rapor siswa yaitu baik dan melampaui batas ketuntasan minimal. Ketiga adalah rasa tanggung jawab siswa terhadap tugas yang diberikan. Hal ini dilihat saat siswa mengerjakan pekerjaan rumah dan tugas-tugas sekolah. Dan yang keempat adalah tingkat kedisiplinan siswa harus baik yaitu dengan melihat ketepatan waktu siswa ketika datang ke sekolah, saat upacara bendera ataupun kegiatan sekolah lainnya." (21 Maret 2016).

Berdasarkan gambar yang penulis peroleh dalam penelitian, dapat diketahui bahwa di kelas IV SDN 77/1 Penerokan terdapat struktur organisasi kelas yang meliputi ketua kelas, wakil ketua kelas, sekretaris, bendahara serta seksi-seksi bidang seperti bidang olahraga, seni, kebersihan, keamanan, dan sosial. 


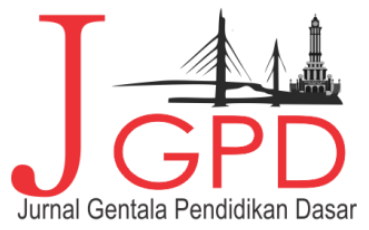

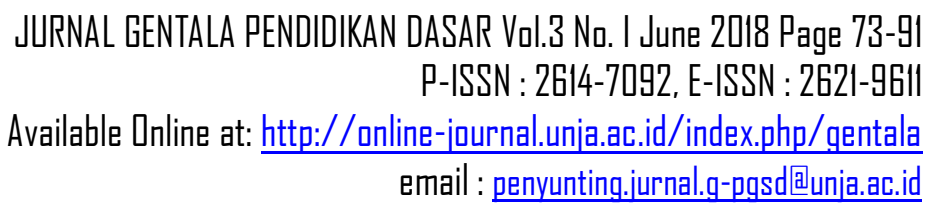

2) Penugasaan Siswa

Berdasarkan hasil observasi yang penulis lakukan pada tanggal 17 Maret 2016 diketahui bahwa dalam pelaksanaannya tugas sebagai anggota organisasi kelas, siswa selalu berusaha untuk melaksanakan tugas sesuai jabatan yang dimilikinya yaitu sebagai ketua kelas memiliki tugas mengatur kelas agar selalu rapi dan siap untuk menerima materi pelajaran, wakil ketua kelas bertugas untuk membantu ketua kelas menertibkan kelas dan menggantikan tugas ketua kelas jika ketua kelas tidak ada. Selain itu sekretaris bertugas untuk mencatat hal-hal yang penting yang berkaitan dengan kelas dan bendahara yang memiliki tugas sebagai pengumpul dana jika ada keperluan kelas seperti infak, menjenguk teman atau guru yang sakit. Akan tetapi, anggota struktur organsasi kelas belum dapat menjalankan tugas secara maksimal seperti seksi pada bidang-bidang tertentu. Tugas seksi seringkali dilimpahkan kepada ketua kelas. Hal ini tidak sesuai dengan pembagian tugas dari srtuktur organisasi yang telah dibuat.

Hasil observasi yang penulis lakukan, didukung dengan hasil wawancara penulis terhadap guru SDN 77/1 Penerokan mengenai penugasan siswa yaitu sebagai berikut:

GR: "Saya akan memberikan tugas sesuai dengan kedudukan siswa di dalam organisasi kelas.

Seorang ketua kelas bertugas untuk dapat mengatur dan mengkondisikan eman-temannya di kelas agar selalu siap menerima embelajaran. Seorang wakil ketua kelas memiliki tugas untuk membantu tugas ketua kelas. Sekretaris bertugas untuk mencatat hal penting yang berkaitan dengan kelas dan bendahara bertugas untuk mengumpulkan dana untuk keperluan kelas. Selain itu, organisasi kelas juga memiliki seksi pada bidang tertentu yaitu bidang olahraga, seni, kebersihan, keamanan dan sosial yang memiliki tugas sesuai bidangnya masing-masing." (23 Maret 2016).

Berdasarkan gambar yang penulis peroleh dalam penelitian, dapat diketahui bahwa di kelas IV SDN 77/1 Penerokan ketua kelas melaksanakan tugas sebagai pengatur dan penanggung jawab kelas yaitu dengan menyiapkan kelas agar siap menerima pelajaran di kelas.

3) Pembimbingan siswa

Copyright (c) 2018 Budi Purnomo, Febliana Aulia Attribution-NonCommercial-ShareAlike 4.0 International License $81 \mid \mathrm{P}$ ag e 


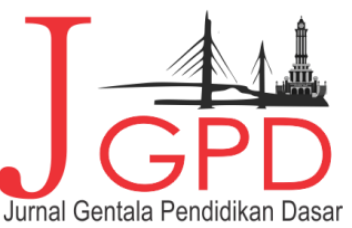

JURNAL GENTALA PENDIDIKAN DASAR Vol.3 No. I June 20I8 Page 73-9I
P-ISSN : 2614-7092, E-ISSN : 2621-96II
Available Online at: http:///nline-jpurnal.unja.ac.id/index.php/gentala
email : penyunting.jurnal.g-pgsd国unja.ac.id

Berdasarkan hasil observasi yang penulis lakukan pada tanggal 22 Maret 2016 dapat diketahui bahwa dalam melaksanakan tugasnya, anggota kelas selalu dibimbing oleh guru. Guru memberikan pengawasan terhadap pelaksanaan tugas dari masing-masing siswa yang memiliki jabatan dalam organisasi kelas seperti ketua kelas yang memiliki tugas untuk menyiapkan kelas sebelum pembelajaran di mulai atau memamnggil guru ketika guru belum hadir di kelas. Guru selalu memberi pengarahan kepada siswa untuk dapat mengelola kelas secara baik sehingga kelas dapat menjadi sarana pendidikan yang memadai dan proses pembelajaran dapat berjalan secara optimal.

Hasil observasi yang penulis lakukan, didukung dengan hasil wawancara penulis terhadap guru SDN 77/1 Penerokan mengenai pembimbingaan siswa yaitu sebagai berikut:

GR: "Kalau mengawasi, saya selalu mengawasi siswa dalam melaksanakan tugasnya terutama tugas yang berkaitan dengan kelancaran kegiatan belajar mengajar di kelas. Saya juga selalu menanyakan kepada siswa terlebih dahulu mengenai segala hal yang berkaitan dengan keadaan kelas tempat belajar. Hal ini agar siswa merasa nyaman dengan kelas tempat mereka belajara." (26 Maret 2016).

Berdasarkan gambar yang penulis peroleh dalam penelitian, dapat diketahui bahwa di kelas IV SDN 77/1 Penerokan guru melakukan pengawaan terhadap kegiatan siswa di dalam mengatur keadaan kelas mereka untuk belajar.

Dari hasi wawancara, observasi dan dokumentasi yang dilakukan, dapat diketahui bahwa guru kelas IV SDN 77/1 Penerokan membuat struktur organisasi kelas meliputi ketua kelas, wakil ketua kelas, sekretaris, bendahara serta seksi-seksi bidang seperti bidang olahraga, seni, kebersihan, keamanan dan sosial. Pembuatan struktur organisasi kelas bertujuan agar guru dapat lebih mudah untuk mengontrol dan mengkondisikan kelas menjadi kelas yang baik dan nyaman sebagai tempat penyelenggaraan pedidikan. Dalam pelaksanaannya tugas sebagai anggota organisasi kelas, siswa selalu berusaha untuk melaksanakan tugas sesuai jabatan yang dimilikinya. Selain itu guru memberikan pengawasan terhadap pelaksanaan tugas dari masingmasing siswa yang memiliki jabatan dalam organisasi kelas.

Copyright (c) 2018 Budi Purnomo, Febliana Aulia Attribution-NonCommercial-ShareAlike 4.0 International License 82 | P a g e 
Tabel 4. Deskripsi Hasil Penelitian Pengaturan Siswa

\begin{tabular}{|c|c|c|}
\hline No & Indikator & Deskripsi \\
\hline 1 & $\begin{array}{l}\text { Pembentukan } \\
\text { Organisasi Siswa }\end{array}$ & $\begin{array}{l}\text { Kelas IV SDN 77/1 Penerokan membuat struktur organisasi kelas meliputi } \\
\text { ketua kelas, wakil ketua kelas, sekretaris, bendahara serta seksi-seksi bidang } \\
\text { seperti bidang olahraga, seni, kebersihan, keamanan dan sosial. Pembuatan } \\
\text { struktur organisasi kelas bertujuan agar guru dapat lebih mudah untuk } \\
\text { mengontrol dan mengkondisikan kelas menjadi kelas yang baik dan nyaman } \\
\text { sebagai tempat penyelenggaraan pedidikan. }\end{array}$ \\
\hline 2 & Penugasan Siswa & $\begin{array}{l}\text { dalam pelaksanaannya tugas sebagai anggota organisasi kelas, siswa selalu } \\
\text { berusaha untuk melaksanakan tugas sesuai jabatan yang dimilikinya yaitu } \\
\text { sebagai ketua kelas memiliki tugas mengatur kelas agar selalu rapi dan siap } \\
\text { untuk menerima materi pelajaran, wakil ketua kelas bertugas untuk } \\
\text { membantu ketua kelas menertibkan kelas dan menggantikan tugas ketua } \\
\text { kelas jika ketua kelas tidak ada. Selain itu sekretaris bertugas untuk } \\
\text { mencatat hal-hal yang penting yang berkaitan dengan kelas dan bendahara } \\
\text { yang memiliki tugas sebagai pengumpul dana jika ada keperluan kelas } \\
\text { seperti infak, menjenguk teman atau guru yang sakit. Akan tetapi, anggota } \\
\text { struktur organsasi kelas belum dapat menjalankan tugas secara maksimal } \\
\text { seperti seksi pada bidang-bidang tertentu. Tugas seksi seringkali } \\
\text { dilimpahkan kepada ketua kelas. Hal ini tidak sesuai dengan pembagian } \\
\text { tugas dari srtuktur organisasi yang telah dibuat. }\end{array}$ \\
\hline 3 & $\begin{array}{l}\text { Pembimbingan } \\
\text { Siswa }\end{array}$ & $\begin{array}{l}\text { Guru memberikan pengawasan terhadap pelaksanaan tugas dari masing- } \\
\text { masing siswa yang memiliki jabatan dalam organisasi kelas seperti ketua } \\
\text { kelas yang memiliki tugas untuk menyiapkan kelas sebelum pembelajaran } \\
\text { di mulai atau memamnggil guru ketika guru belum hadir di kelas. Guru } \\
\text { selalu memberi pengarahan kepada siswa untuk dapat mengelola kelas } \\
\text { secara baik sehingga kelas dapat menjadi sarana pendidikan yang memadai } \\
\text { dan proses pembelajaran dapat berjalan secara optimal. }\end{array}$ \\
\hline
\end{tabular}

\section{Pengaturan Fasilitas di Kelas}

1) Pengaturan tempat duduk 


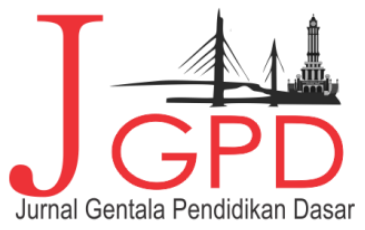

JURNAL GENTALA PENDIDIKAN DASAR Vol.3 No. I June 20I8 Page 73-9I
P-ISSN : 2614-7092, E-ISSN : 2621-96II
Available Online at: http:///nline-jpurnal.unja.ac.id/index.php/gentala
email : penyunting.jurnal.g-pgsd国unja.ac.id

Berdasarkan hasil observasi yang penulis lakukan pada tanggal 28 Maret 2016 dapat diketahui bahwa di kelas IV SDN 77/1 Penerokan tempat duduk diatur dengan satu arah yaitu semua siswa menghadap ke papan tulis. Siswa duduk secara berpasangan. Selain itu, setiap bangku yang terdiri dari dua orang siswa memiliki jarak dengan bangku lain. Jarak tersebut menjdi jalan bagi guru ataupun siswa sehingga siswa dan guru lebih leluasa untuk berjalan.

Kemudian penulis melakukan wawancara terhadap guru dan beberapa siswa kelas IV SDN 77/1 Penerokan mengenai pengaturan tempat duduk siswa yaitu sebagai berikut:

GR : "tempat duduk di kelas IV aya atur dengan menghadap satu arah yaitu menghadap ke papan tulis. Kemudian, saya mengatur siswa agar dapat duduk secara berpasangan. Pasangan dari masing-masing bangku adalah siswa yang memiliki kemampuan baik akan saya pasangkan dengan siswa yang memiliki kemampuan yang kurang baik agar bisa saling belajar dan mengajarkan, siswa yang suka atau terbiasa ribut di kelas akan saya paasangkan dengan siswa yang kurang suka untuk ribut atau pendiam. " (29 Maret 2016).

AP : “yang ngatur tempat duduk itu guru kak.” (29 Maret 2016)

$R R$ :"bu guru yang ngatur tempat duduknya, kami gak bisa milih mau duduk dengan siapa kak.” (29 Maret 2016).

BS : "ibu yang mindahin tempat duduknya kak" (29 Maret 2016).

Berdasarkan gambar yang penulis peroleh dalam penelitian, dapat diketahui bahwa di kelas IV SDN 77/1 Penerokan siswa duduk secara berpasangan dan mengarah ke depan kelas. Sedangkan guru berada di sebelah kiri siswa.

2) Pengaturan alat pengajaran

Berdasarkan hasil observasi yang penulis lakukan pada tanggal 30 Maret 2016 dapat diketahui bahwa di kelas IV SDN 77/1 Penerokan terdapat beberapa alat pengajaran salah satunya adalah gambar pahlawan. Gambar pahlawan Indonesia digantungkan di dinding kelas dengan rapi, walaupun jumlahnya tidak terlalu banyak. Hal ini dilakukan agar siswa dapat mengetahui dan mengenali pahlawan yang berjuang untuk kemerdekaan Indonesia sesuai dengan pembelajaran IPS.

Copyright (c) 2018 Budi Purnomo, Febliana Aulia Attribution-NonCommercial-ShareAlike 4.0 International License 


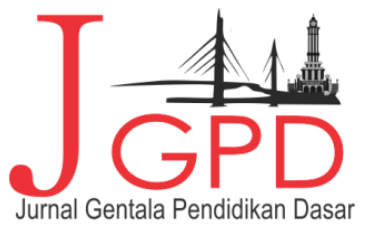

JURNAL GENTALA PENDIDIKAN DASAR Vol.3 No. I June 2018 Page 73-91

P-ISSN : 2614-7092, E-ISSN : 2621-9611

Available Online at: http://online-journal.unja.ac.id/index.php/gentala

email : penyunting.jurnal.g-pgsd回unja.ac.id

Selain gambar pahlawan, terdapat gambar rumah adat dan pakaian adat seluruh provinsi yang ada di Indonesia. Gambar tersebut merupakan salah satu alat pelajaran bagi siswa untuk pembelajaran IPS. Ada juga beberapa alat pengajaran yang disimpan di lemari kelas seperti jam , busur dan jangka sebagai alat pelajaran matematika serta buku-buku pendamping lain yang berkaitan dengan pembelajaran di kelas IV.

Kemudian penulis melakukan wawancara terhadap guru dan beberapa siswa kelas IV SDN 77/1 Penerokan mengenai pengaturan alat pengajaran yaitu sebagai berikut:

GR : "ada beberapa alat pengajaran yang digunakan seperti gambar pahlawan. Gambargambar tersebut digantung sedemikian rupa sehingga selain dapat digunakan sebagai sumber belajar, juga dapat digunakan untuk menghias kelas. Sedangkankan alat pegajaran yang lain yang tidak dapat digantung, saya letakan di lemari kelas agar tidak rusak. " (31 Maret 2016).

AP : "alat-alat peraga ada di dalam lemari kak, disimpan ibu guru. Kalau mau digunakan baru dikeluarkan dari lemari" (31 Maret 2016)

RR : "alat belajar ada di lemari kak" (31 Maret 2016).

BS : "biasanya bu guru ngambil alat untuk belajar dari lemari kak" (31 Maret 2016).

Berdasarkan gambar yang penulis peroleh dalam penelitian, dapat diketahui bahwa di kelas IV SDN 77/1 Penerokan gambar-gambar pahlawan indonesia digantung pada dinding kelas. Selain itu, kelas juga memiliki lemari sebagai tempat penyimpanan alat -alat yang dibutuhkan dalam pembelajaran.

3) Penataan keindahan dan kebersihan ruangan kelas

Berdasarkan hasil observasi yang penulis lakukan pada tanggal 1 April 2016 dapat diketahui bahwa kelas IV SDN 77/1 Penerokan selalu menjaga kebersihan kelas tempat belajar siswa. hal ini dibuktikan dengan adanya jadwal piket kelas.

Setelah kebersihan kelas terjaga, kelas juga ditata dengan rapi seperi tempat sampah yang diletakkan di luar ruangan, sapu dan alat kebersihan lainnya diletakkan di belakang kelas, serta terdapat beberapa bunga yang menghiasi pekarangan kelas sehingga menjadikan suasana kelas

Copyright (c) 2018 Budi Purnomo, Febliana Aulia Attribution-NonCommercial-ShareAlike 4.0 International License $85 \mid$ P a g e 


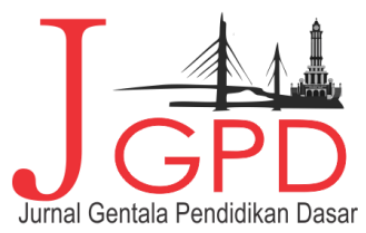

JURNAL gENTALA PENDIDIKAN DASAR Vol.3 No. I June 2018 Page 73-91

P-ISSN : 2614-7092, E-ISSN : 2621-9611

Available Online at: http://online-journal.unja.ac.id/index.php/gentala

email : penyunting.jurnal.g-pgsd国unja.ac.id

lebih rapi dan nyaman untuk siswa belajar. akan tetapi, terkadang jika sudah siang hari, kelas menjadi sedikit kotor dan berdebu karena siswa keluar masuk kelas sehingga debu dari sepatu terbawa hingga ke dalam kelas.

Kemudian penulis melakukan wawancara terhadap guru dan beberapa siswa kelas IV SDN 77/1 Penerokan mengenai penataan keindahan dan kebersihan kelas yaitu sebagai berikut:

GR: "kalau mengenai kebersihan, saya membuat jadwal piket bagi siswa sehingga siswa dapat bertanggung jawab membersihkan kelas sesuai dengan jadwal piket yang teah ditentukan.

Selain itu, saya berusaha membiasakan siswa untuk membuang sampah pada tepatnya dengan menyediakan tempat sampah di luar kelas. Sedangkan untuk keindahan, saya mengajak siswa untuk menenam beberapa bunga di pekarangan kelas. Walaupun tdak banyak tapi cukup membantu membuat kelas menjadi lebih segar dan indah." (8 April 2016).

AP : "kami ada jadwal piketnya kak" (8 April 2016)

$R R$ : "kami menyapu lantai dan menyiram bunga kak" (8 April 2016).

BS : "pake piket kak, trus ada juga yang bawa bunga ke sekolah kak" (8 April 2016).

Berdasarkan gambar yang penulis peroleh dalam penelitian, dapat diketahui bahwa di kelas IV SDN 77/1 Penerokan siswa membersihkan kelas dengan menyapu dan membuang sampah pada tempatnya. Kemudian siswa juga menyiram bunga yang ada di pekarangan kelas agar terlihat asri.

\section{4) Ventilasi dan Pengaturan Cahaya}

Berdasarkan hasil observasi yang penulis lakukan pada tanggal 4 April 2016 dapat diketahui bahwa kelas IV SDN 77/1 Penerokan memiliki jendela yang banyak. Hal ini bertujuan agar cahaya matahari dapat masuk ke dalam ruang kelas. Selain itu, juga terdapat lampu sebagi penerangan jika cuaca mendung atau hujan dan sinar matahari tidak ada.

Kemudian penulis melakukan wawancara terhadap guru dan beberapa siswa kelas IV SDN 77/1 Penerokan mengenai ventilasi dan pengaturan cahaya di kelas yaitu sebagai berikut:

GR: "kelas kami memiliki ventilasi yang cukup banyak sebagi tempat perganian udara dan juga memiliki jendela sebagai tempat asuknya cahaya matahari. Kalau cuaca sedang mendung

Copyright (c) 2018 Budi Purnomo, Febliana Aulia Attribution-NonCommercial-ShareAlike 4.0 International License 86| P a g e 


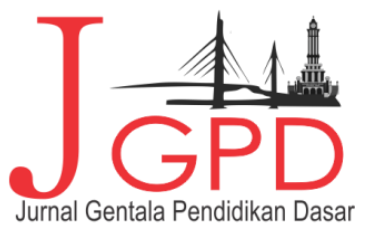

JURNAL geNTALA PENDIDIKAN DASAR Vol.3 No. I June 2018 Page 73-91

P-ISSN : 2614-7092, E-ISSN : 2621-9611

Available Online at: http://online-journal.unja.ac.id/index.php/gentala

email : penyunting.jurnal.g-pgsd国unja.ac.id

sehingga ruang kelas menjadi gelap, maka saya akan menghidupkan lampu untuk menerangi siswa." (5 April 2016).

$A P$ : "terang kak karena banyak jendelanya" (5 April 2016)

RR : "terang sih kak, tapi kadang panas juga" (5 April 2016).

BS : "terang kak" (5 April 2016).

Tabel 5. Deskripsi Hasil Penelitian Pengaturan Fasilitas Kelas

\begin{tabular}{lc}
\hline No & Indikator \\
1 & Pengaturan Tempat Duduk
\end{tabular}

2 Pengaturan Alat-alat Pengajaran

3 Penataan keindahan dan kebersihan ruangan kelas

$4 \quad$ Ventilasi dan Pengaturan Cahaya
Di kelas IV SDN 77/1 Penerokan tempat duduk diatur dengan satu arah yaitu semua siswa menghadap ke papan tulis. Siswa duduk secara berpasangan. Selain itu, setiap bangku yang terdiri dari dua orang siswa memiliki jarak dengan bangku lain.

Kelas IV SDN 77/1 Penerokan terdapat beberapa alat pengajaran salah satunya adalah gambar pahlawan. Gambar pahlawan Indonesia digantungkan di dinding kelas dengan rapi, walaupun jumlahnya tidak terlalu banyak. Hal ini dilakukan agar siswa dapat mengetahui dan mengenali pahlawan yang berjuang untuk kemerdekaan Indonesia sesuai dengan pembelajaran IPS. Selain gambar pahlawan, terdapat gambar rumah adat dan pakaian adat seluruh provinsi yang ada di Indonesia.

SDN 77/1 Penerokan selalu menjaga kebersihan kelas tempat belajar siswa. Hal ini dibuktikan dengan adanya jadwal piket kelas. Dengan adanya jadwal piket tersebut, siswa akan menjalankan tugasnya seperti menyapu lantai kelas, menyapu pekarangan kelas, menyiram bunga dan membuang sampah.

SDN 77/1 Penerokan memiliki jendela yang banyak. Hal ini bertujuan agar cahaya matahari dapat masuk ke dalam ruang kelas. Selain itu, juga terdapat lampu sebagi penerangan jika cuaca mendung atau hujan dan sinar matahari tidak ada. Akan tetapi, tidak terdapat tirai penutup jendela sehingga siswa tidak dapat mengatur berapa banyak cahaya yang dibutuhkan. Selain itu, karena tidak adanya tirai, terkadang sinar matahari membuat siswa kepanasan karena terlalu terik danmenyilaikan sehingga mengenai mereka saat sedang belajar.

\section{Pembahasan}




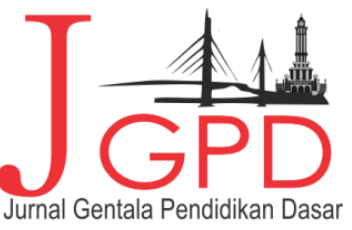

JURNAL GENTALA PENDIDIKAN DASAR Vol.3 No. I June 20I8 Page 73-9I
P-ISSN : 2614-7092, E-ISSN : 2621-96II
Available Online at: http:///nline-jpurnal.unja.ac.id/index.php/gentala
email : penyunting.jurnal.g-pgsd国unja.ac.id

1) Pengaturan siswa di kelas

Pengelolaan kelas di SDN 77/1 Penerokan diawali dengan membuat struktur organisasi kelas meliputi ketua kelas, wakil ketua kelas, sekretaris, bendahara serta seksi-seksi bidang seperti bidang olahraga, seni, kebersihan, keamanan dan sosial. Pembuatan struktur organisasi kelas bertujuan agar guru dapat lebih mudah untuk mengontrol dan mengkondisikan kelas menjadi kelas yang baik dan nyaman sebagai tempat penyelenggaraan pedidikan. Dalam pelaksanaannya tugas sebagai anggota organisasi kelas, siswa selalu berusaha untuk melaksanakan tugas sesuai jabatan yang dimilikinya. Selain itu guru memberikan pengawasan terhadap pelaksanaan tugas dari masing-masing siswa yang memiliki jabatan dalam organisasi kelas.

Hal ini sesuai dengan pendapat Djamarah, dkk. (2005:180) yaitu dalam rangka memeperkecil masalah gangguan dalam pengelolaan kelas, prinsip-prinsip pengelolaan kelas dapat dipergunakan yaitu dengan mengembangkan disiplin diri sendiri. Karena itu, guru sebaiknya selalu mendorong anak didik untuk melaksanakan disiplin diri sendiri dan guru sendiri hendaknya menjadi teladan mengenai pengendalian diri dan pelaksanaan tanggung jawab. Jadi guru harus disiplin dalam segala hal bila ingin anak didiknya ikut berdisiplin dalam segala hal.

\section{2) Pengaturan fasilitas kelas}

Selain pengaturan siswa di dalam kelas, pengelolaan kelas juga mencakup pengaturan fasilitas kelas. Dalam mengatur fasilitas kelas, SDN 77/1 Penerokan mengatur tempat duduk siswa dengan satu arah yaitu semua siswa menghadap ke papan tulis. Siswa duduk secara berpasangan. Meja guru berada di depan sebelah kiri siswa. sedangkan papan tulis berada di tengah. Sedangkan alat pengajaran seperti gambar pahlawan Indonesia digantungkan di dinding kelas dengan rapi. Selain gambar pahlawan, terdapat gambar rumah adat dan pakaian adat seluruh provinsi yang ada di Indonesia.

Kelas IV SDN 77/1 Penerokan selalu menjaga kebersihan kelas tempat belajar siswa dengan adanya jadwal piket kelas. Di kelas juga terdapat tempat sampah sehingga siswa dapat membuang sampah pada tempatnya dan tidak membuang sampah sembarangan. Setelah kebersihan kelas terjaga, kelas juga ditata dengan rapi seperi tempat sampah yang diletakkan di luar ruangan, sapu dan alat kebersihan lainnya diletakkan di belakang kelas, serta terdapat

Copyright (c) 2018 Budi Purnomo, Febliana Aulia Attribution-NonCommercial-ShareAlike 4.0 International License 


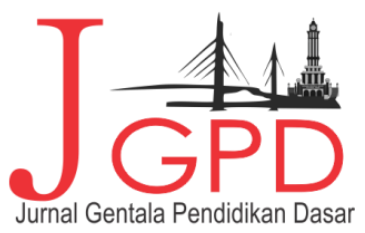

JURNAL geNTALA PENDIDIKAN DASAR Vol.3 №. I June 2018 Page 73-91

P-ISSN : 2614-7092, E-ISSN : 2621-9611

Available Online at: http://online-journal.unja.ac.id/index.php/gentala

email : penyunting.jurnal.g-pgsd国unja.ac.id

beberapa bunga yang menghiasi pekarangan kelas. Terdapat banyak jendela sebagai tempa masuknya cahaya dan juga terdapat banyak ventilasi sebagai tempa keluar masuknya udara dari dan ke dalam kelas sehingga siswa dapat belajar dengan baik.

Hal ini sesuai dengan pendapat Ahmad (2004:2) bahwa tujuan pengelolaan kelas adalah mewujudkan situasi dan kondisi kelas, baik sebgai lingkungan belajar maupun sebgai kelompok belajar yang memungkinkan siswa untuk mengembangkan kemampuan semaksimal mungkin, menghilangkan berbagai hambatan yang dapat menghalangi terwujudnya interaksi belajar mengajar serta menyediakan dan mengatur fasilitas serta perabot belajar yang mendukung dan memungkinkan siswa belajar sesuai dengan lingkungan sosial, emosional, dan intelektual siswa dalam kelas.

\section{KESIMPULAN DAN IMPLIKASI}

\section{Kesimpulan}

Berdasarkan hasil penelitian dan pembahasan mengenai pelaksanaan pengelolaan kelas di SDN 77/1 Penerokan terlebih dahulu mengatur siswa yang berada di dalam kelas yaitu dengan membuat struktur organisasi kelas meliputi ketua kelas, wakil ketua kelas, sekretaris, bendahara serta seksi-seksi bidang seperti bidang olahraga, seni, kebersihan, keamanan dan sosial. Dalam pelaksanaannya tugas sebagai anggota organisasi kelas, siswa selalu berusaha untuk melaksanakan tugas sesuai jabatan yang dimilikinya. Selain itu guru memberikan pengawasan terhadap pelaksanaan tugas dari masing-masing siswa yang memiliki jabatan dalam organisasi kelas.

Setelah itu, pelaksanaan pegelolaan kelas dilanjutkan dengan pengaturan fasilitas kelas meliputi mengatur tempat duduk siswa yaitu semua siswa menghadap ke papan tulis. Siswa duduk secara berpasangan. Meja guru berada di depan sebelah kiri siswa, sedangkan papan tulis berada di tengah. Alat pengajaran seperti gambar pahlawan dan gambar rumah adat dan pakaian adat seluruh provinsi yang ada di Indonesia digantungkan di dinding kelas dengan rapi, walaupun jumlahnya tidak terlalu banyak. 


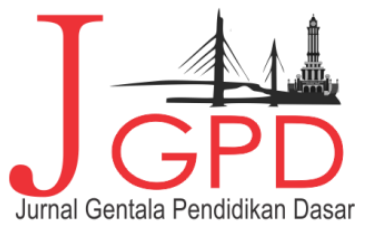

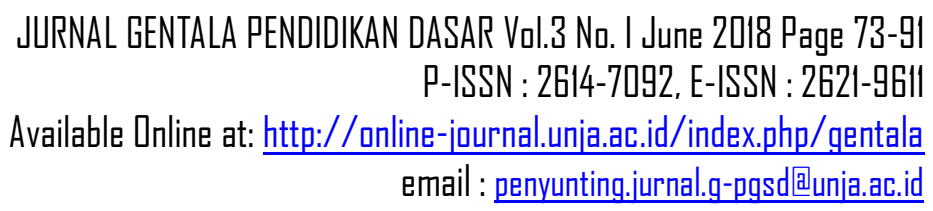

Kebersihan kelas tempat belajar selalu dijaga oleh siswa. hal ini dibuktikan dengan adanya jadwal piket kelas. Dengan adanya jadwal piket tersebut, siswa akan menjalankan tugasnya seperti menyapu lantai kelas, menyapu pekarangan kelas, menyiram bunga dan membuang sampah. Setelah kebersihan kelas terjaga, kelas juga ditata dengan rapi seperi tempat sampah yang diletakkan di luar ruangan, sapu dan alat kebersihan lainnya diletakkan di belakang kelas, serta terdapat beberapa bunga yang menghiasi pekarangan kelas sehingga menjadikan suasana kelas lebih rapi dan nyaman untuk siswa belajar.

\section{Implikasi}

Sehubungan dengan hasil penelitian ini, maka implikasi penelitian dijabarkan berikut ini :

1. Pelaksanaan pengeolaan kelas dapat berjalan secara optimal, tentunya dengan dukungan pihak sekolah.

2. Kepada guru dapat selalu memberikan bimbngan kepada siswa agar dapat mengkondisikan kelas menjadi tempat belajar yang baik dan nyaman.

3. Kepada peneliti lain untuk dapat mengkaji dan meneliti ulang masalah ini, sebab hasil penelitian ini masih jauh dari kata sempurna. Hal ini dikarenakan oleh keterbatasan pengetahuan dan metodologi penulis, namun demikian semoga hasil penelitian ini dapat dijadikan acuan untuk penelitian selanjutya.

\section{UCAPAN TERIMAKASIH}

Dalam kesempatan ini disampaikan terima kasih yang setulus-tulusnya kepada Bapak/lbu pengelola Jurnal Gentala Pendidikan Dasar PGSD FKIP Universitas Jambi atas kerjasamanya sehingga karya ilmiah ini dapat diterbitkan. 


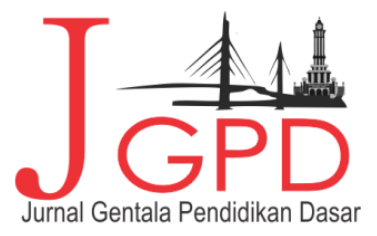

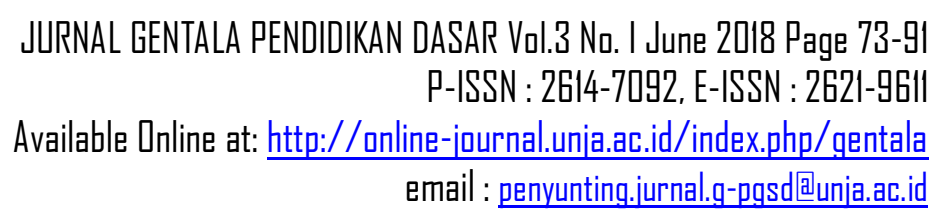

DAFTAR PUSTAKA

Arikunto, Suharsimi. (2010). Prosedur Penelitian Suatu Pendekatan Praktik. Jakarta: PT Rineka Cipta.

Ahmad Rohani. 2004. Pengelolaan Pengajaran. Jakarta. PT. Rineka Cipta

Ahmad, Sobri. 2004. Strategi Belajar Mengajar. Jakarta. Ciputat Press

Danim Sudarwan. 2006. Fisi Baru Manajemen Sekolah. Jakarta PT: Bumi Aksara

Djamarah, Syaiful Bahri. 2005. Guru dan Anak Didik Dalam Interaksi Edukatif. Jakarta: Rineka Cipta.

Fatturohman, Pupuh. M Sobri, S. 2007. Strategi Belajar Mengajar Melalui Penanaman Konsep Umum dan Konsep Islam. Bandung:Refika Aditama.

Sutopo. 2010. Metodologi Penelitian Kualitatif. Surakarta. Sebelas Maret University Press

Sukmadinata, Nana Syaodih. 2011. Metode Penelitian Pendidikan. Bandung : PT Remaja Rosdakarya

Sugiyono. 2010. Metode Penelitian Pendidikan (Pendekatan Kuantitatif, Kualitatif, dan R\&D). Bandung: Alfabeta.

Satori Djam'an, Komariah Aan. 2011. Metode Penelitian Kualitatif. Alfabeta: Bandung

Zain, Aswan. 2013. Strategi Belajar Mengajar. Jakarta: Rineka Cipta. 